\title{
Feasibility Study on Blast Furnace Ironmaking System Integrated with Methanol Synthesis for Reduction of Carbon Dioxide Emission and Effective Use of Exergy
}

\author{
Tomohiro AKIYAMA, Hirotaka SATO, Atsushi MURAMATSU and Jun-ichiro YAGI \\ Institute for Advanced Materials Processing, Tohoku University, Katahira, Aoba-ku, Sendai, Miyagi-ken, 980 Japan.
}

(Received on February 25, 1993; accepted in final form on September 24, 1993)

\begin{abstract}
Partial replacement of coke by natural gas and production of methanol from the off gas will result in the integrated blast furnace ironmaking system with methanol synthesis. According to the requirement of reduction of $\mathrm{CO}_{2}$ emission and energy savings, the feasibility study of the integrated system was conducted. Operating data of the new system was calculated by a mathematical model based on the heat and mass balances. The effect of operating conditions, such as replacement amount of coke and conversion factor to methanol, on the total emission of greenhouse effect gas (GEG) and on the exergy loss was examined. The exergy loss and the GEG emission decreased with increase in the replacement amount of coke by natural gas and the conversion factor. In the operation case that has $300 \mathrm{~kg}$-coke $/ \mathrm{thm}$ and $219 \mathrm{Nm}^{3}$-natural gas/thm in fuel ratio and $2.3 \%$ in conversion factor, the total amount of GEG decreased from 542 to $454 \mathrm{~kg} / \mathrm{thm}$ and the sum of exergy loss also decreased from 9.0 to $8.2 \mathrm{GJ} /$ thm.
\end{abstract}

KEY WORDS: ironmaking; blast furnace; carbon dioxide; methanol synthesis; natural gas injection; exergy analysis; system integration.

\section{Introduction}

Ironmaking industry consumes much energy and then generates significant amount of waste gas. The waste gas emitted during combustion contaminates the environment, to the extent affecting the global climate and threatening the future habitability of the earth. The content of carbon dioxide in the atmosphere makes up only a thirtieth of $1 \%$ of atmosphere. But together with other greenhouse effect gases (GEG) it plays a role in changing the earth's climate by catching and trapping the heat radiated from the earth near the surface. The previous papers ${ }^{1,2)}$ of the authors revealed the location and magnitude of both GEG emission and exergy loss within the ironmaking systems.

Reduction in the $\mathrm{CO}_{2}$ emission rate probably will not be accomplished without a massive switch to nonfossileenergy sources. Until such energy sources supplant coal, oil and natural gas, the technology challenge must be directed to: 1) exploit the fuels more efficiently, 2) replace coal by natural gas and 3) reconvert and sequester $\mathrm{CO}_{2}$ emissions. The most important item is efficiency improvement, because it is often economically and environmentally attractive. Some basic thermodynamic laws tell us how to reduce energy consumption. According to the laws energy is neither consumed nor created. What is consumed is the capacity of energy to do work. This is exactly the concept of exergy, ${ }^{1-6)}$ which gives system designers a 'new point of view' for op- timization. Second, any practical transformation that converts energy from one form to another is accompanied by exergy loss. Therefore, an even better solution than using energy efficiently is no use of energy at all. As a result, some processes that apparently have little relation to energy in agglomeration process of ore and coal, such as the recycling of scrap or iron-bath type smelting reduction, may have an enormous impact on energy consumption. Recycling and smelting reduction processes bypass the most energy-intensive steps for processing the charging material. ${ }^{1,2)}$ Consequently, reduction of exergy inflow and increase in exergy efficiency are the most successful method to enhance effective use of exergy.

The natural gas option leads to improvements in efficiency, and it is appealing for various reasons. From a viewpoint of fuel, $\mathrm{CO}_{2}$ converted from natural gas is around $50 \%$ of that from coal in a unit calorific value. Moreover, in comparison with coal, the use of natural gas as fuel has various advantages such as simplicity of gas-handling equipment, low useless components and less sulfur content. On the other hand, in order to realize a plan to substitute natural gas for coal in the ironmaking system, technologies to solve following problems must be established. First, natural gas is much less abundant. Therefore, nonfossile energy technology must be accepted until natural gas is entirely consumed. Second, leakage of natural gas during extraction and transport could partially offset the advantage of its use, because 
$\mathrm{CH}_{4}$ is a kind of greenhouse effect gas and is more efficient absorber of infrared radiation than $\mathrm{CO}_{2}$.

Historically, the changing price structure and availability of natural gas have often made it competitive with coke. Operation of a blast furnace with injection of natural gas has been carried out in several countries, for example USA, ${ }^{7)}$ Australia, ${ }^{8)} \mathrm{CIS}^{9-11)}$ (formerly USSR) and Hungry. ${ }^{12)}$ Particularly, there were many reports in 1960's in CIS, which showed practical operations of natural gas injection up to about $100 \mathrm{Nm}^{3}$ per $1 \mathrm{t}$-hot metal. Recently, natural gas injection to a blast furnace has been also focussed from a viewpoint of $\mathrm{CO}_{2}$ problem as mentioned above. The purpose of this study is to propose an improved ironmaking system using natural gas for reduction of GEG emission and for effective use of exergy. In the system, natural gas is injected to a blast furnace and methanol is synthesized from the top gas. The mathematical model based on heat and mass balances predicted the various operating data which is necessary for the exergy analysis. Effect of operating conditions, such as amount of coke replaced by natural gas and conversion ratio to methanol, on GEG emission and exergy loss was examined for the assessment of the system proposed.

\section{Improved Ironmaking System Proposed}

Figure 1 shows a typical conventional blast furnace ironmaking system, which consists of five unit processes: coke oven, sintering machine, rotary kiln, hot stove and blast furnace. The conventional ironmaking system generates GEG in each process from coal and limestone, which are marked by superscript of \#. Limestone emits carbon dioxide in agglomeration processes according to the reaction of $\mathrm{CaCO}_{3}=\mathrm{CaO}+\mathrm{CO}_{2}$. The blast furnace off gas (BFG) and the coke oven gas (COG) are mostly utilized in other processes within the system. The outflow ratio of the byproduct gas from the system depends on the operation conditions of the ironmaking system.

Dotted lines in Fig. 1 indicate the improved ironmaking system proposed here. Considerable amount of natural gas is injected to a blast furnace resulting in the decrease in coke rate. This system needs also oxygen enrichment in blast air to maintain the desired flame temperature. To reduce GEG emission from the blast furnace, two operation methods can be considered. One method is to reconvert the top gas from a blast furnace and another is to remove carbon content in fossil fuel as solid carbon in advance. In the first method, a part of the top gas is assumed to be converted to methanol $\left(\mathrm{CH}_{3} \mathrm{OH}\right)$. Methanol, which is currently consumed at the rate of $c a .2 \mathrm{Mt} /$ year in Japan, is becoming an essential raw material for a chemical product such as formaldehyde. Moreover, it has been recently focussed as secondary energy, which will be use for vehicles or power generation. Also, the natural gas injection is employed to advantage to the methanol synthesis where the production rate is accelerated by the higher hydrogen concentration, because $\mathrm{H}_{2}$ concentration of the top gas is expected to increase with increasing the injection amount of natural gas; details will be described later. The second method is adopted when the $\mathrm{CO}_{2}$ problem must be solved even if energy efficiency were decreased. Namely, carbon in methane is removed in the form of carbon fiber by chemical vapor deposition (CVD) method $\left(\mathrm{CH}_{4}=\mathrm{C}+2 \mathrm{H}_{2}\right)$ before the injection of natural gas. This leads to hydrogen injection into the blast furnace. Since carbon fiber has high electric conductivity and good mechanical property, it is focussed as a new high grade material. However, this method has two unavoidable disadvantages: one is low energy efficiency due to no combustion of carbon and another is slow reaction rate of CVD. Therefore, the improved ironmaking system in this study adopts only the first method.

Figure 2 shows schematic diagram of the industrial methanol synthesis system. This system consists of three unit processes: steam reformer, catalytic reactor and distillation towers. First, natural gas is reformed to gas mixture of $\mathrm{H}_{2}-\mathrm{CO}-\mathrm{CO}_{2}$ at $750 \mathrm{~K}$ by steam. Next, the gas is introduced to the catalytic reactor at $523 \mathrm{~K}$ under high pressure condition for production of crude methanol. To improve productivity and decrease pressure required for methanol synthesis, various catalysts have been developed. During the period of 1952 to 1965 , all

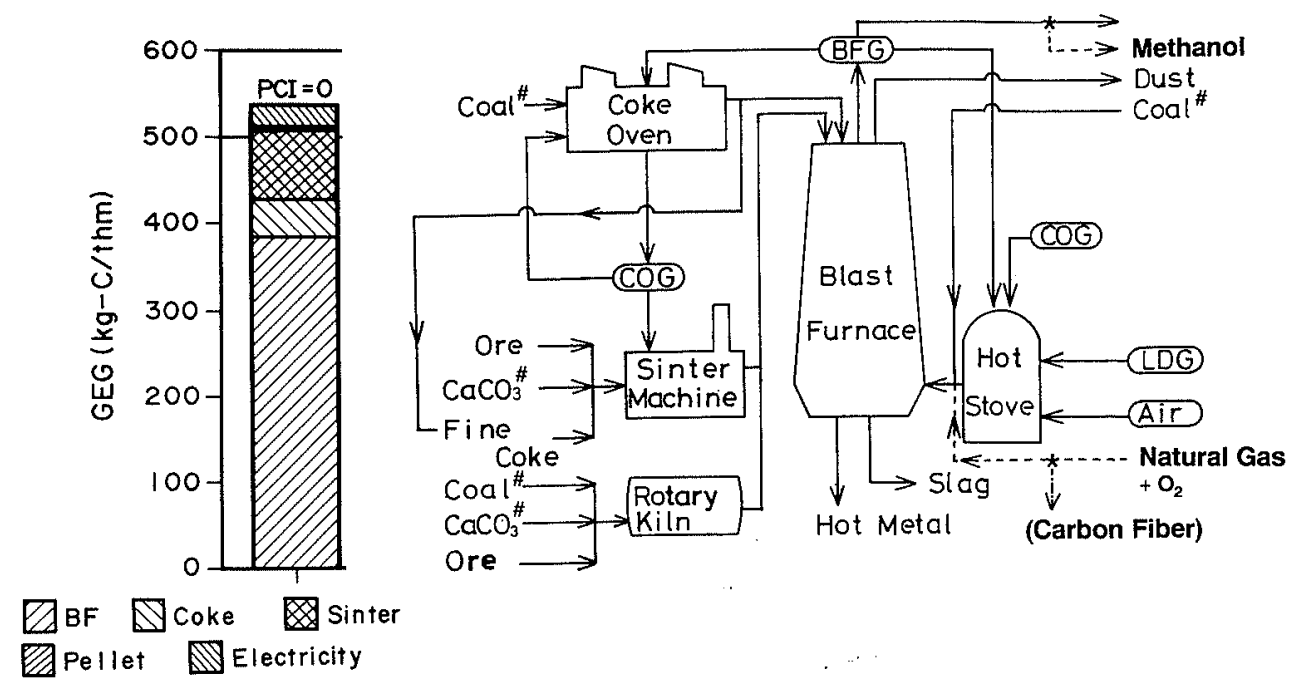

Fig. 1. Schematic diagram of blast furnace ironmaking system and summation of greenhouse effect gas (GEG) emission. (\#; original source of GEG) 


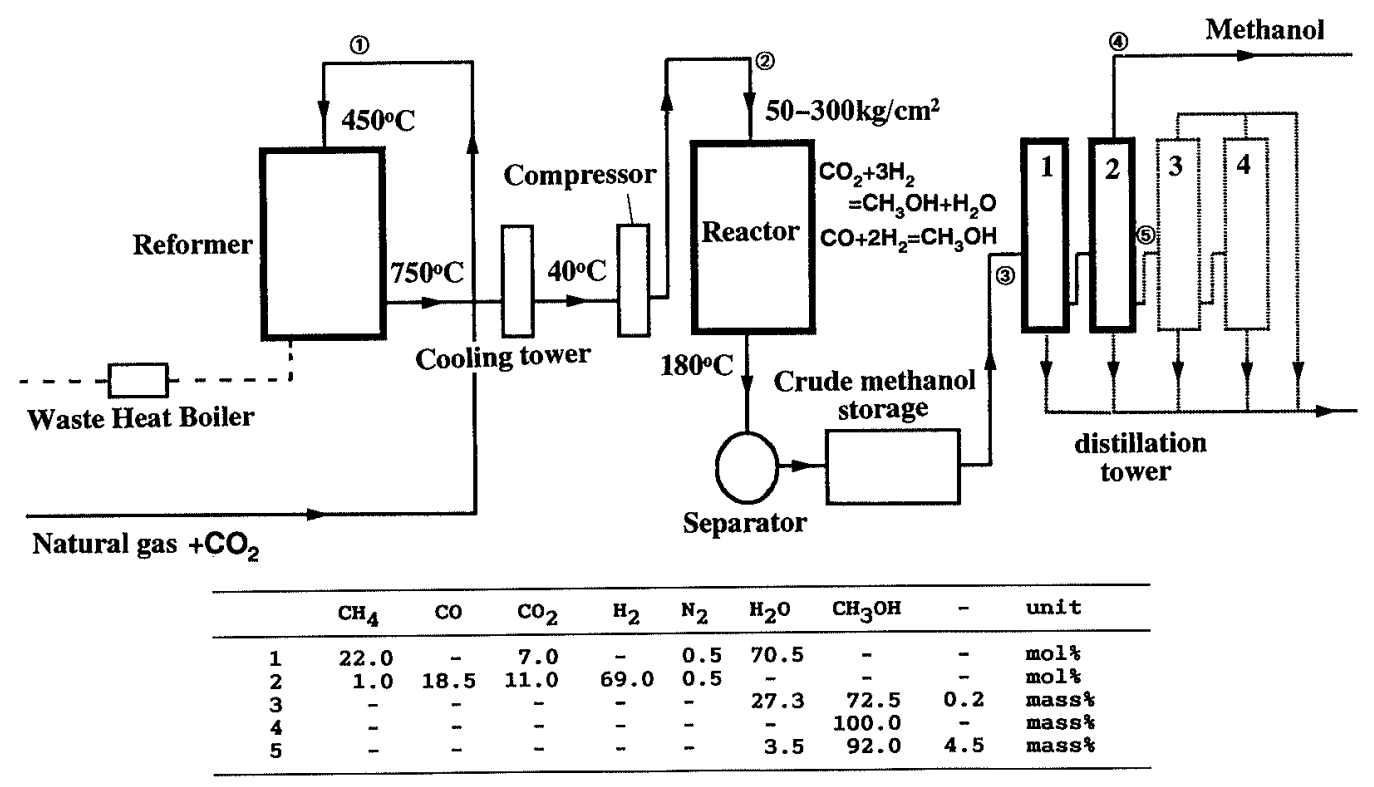

Fig. 2. Typical methanol synthesis system.

Table 1. Operating data and GEG emission in a methanol synthesis system of $600 \mathrm{t} /$ day scale. (Unit: per a ton of methanol)

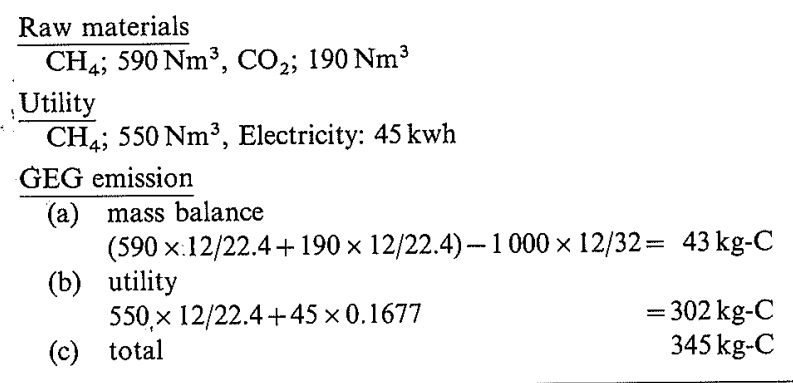

conventional catalysts were composed of $\mathrm{ZnO}$ and $\mathrm{Cr}_{2} \mathrm{O}_{3}$, which was effective in the ranges of 600 to $650 \mathrm{~K}$ and 34 to $40 \mathrm{MPa}$. Cu-based catalysts were lately developed and employed under the moderate conditions; viz. $520 \mathrm{~K}$ and less than $10 \mathrm{MPa}$. Besides, some industrial processes can produce pure methanol at the extremely low pressure, $5 \mathrm{MPa}$, where reduction of energy consumption progresses considerably. Since the reactions of methanol synthesis $\left(\mathrm{CO}_{2}+3 \mathrm{H}_{2}=\mathrm{CH}_{3} \mathrm{OH}+\mathrm{H}_{2} \mathrm{O}\right.$, $\mathrm{CO}+2 \mathrm{H}_{2} \mathrm{O}=\mathrm{CH}_{3} \mathrm{OH}$ ) are exothermic, a cooling device is generally required to be annexed to the reactor. Crude methanol goes through the distillation towers to remove impurities. Table 1 lists the operating data and GEG emission in the industrial methanol synthesis system in the productivity of $600 \mathrm{t} / \mathrm{d}$. Here, the consumption of natural gas for the system is $1140 \mathrm{Nm}^{3} / \mathrm{t}$-methanol as raw material and fuel. Consequently the system emits GEG of $345 \mathrm{~kg}-\mathrm{C} / \mathrm{t}$-methanol. The ironmaking system integrating with the methanol synthesis system is shown in Fig. 3. In this system the steam reforming process in the methanol synthesis system is unnecessary because methane is reformed in the blast furnace. Hence, the top gas from the blast furnace is directly introduced into the catalytic reactor, where methanol can be obtained. Even if the top gas pressure is about $0.25 \mathrm{MPa}$, markedly lower
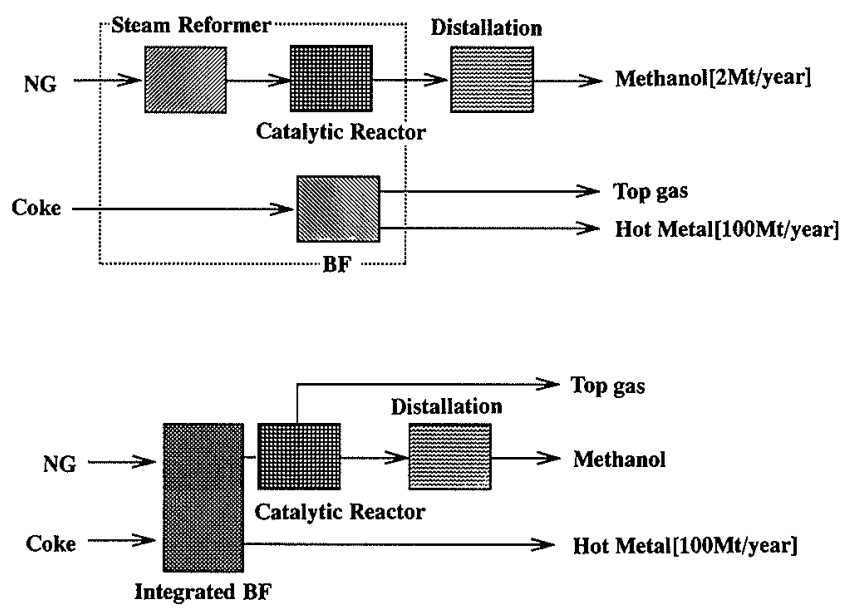

Fig. 3. Concept for the integration of blast furnace ironmaking and methanol synthesis systems.

than that in the conventional methanol synthesis systems, the gas conversion to methanol is thermodynamically possible. Assuming that all methanol demanded in Japan is produced only from the top gas of the existing blast furnaces, the conversion to methanol is calculated to be ca. $2 \%$ of $\mathrm{CO}$ and $\mathrm{CO}_{2}$ in the gas. Therefore, the target of the conversion in the present study is not be so high as the conventional process and then it should be determined on the basis of the energy balance within the whole system. It is to be noted that methanol is yielded by $\mathrm{H}_{2}-\mathrm{CO}_{2}-\mathrm{CO}$ gas even at atmospheric pressure. ${ }^{13)}$

Natural gas injection into a blast furnace and the methanol synthesis from the off gas result in the following advantages:

1) reduction of GEG from a blast furnace due to the injection of natural gas which has low $\mathrm{C} / \mathrm{H}$ ratio.

2) reduction of GEG from a coke oven due to decrease of coke rate in the blast furnace.

3) reduction of GEG from BFG due to the methanol synthesis from the blast furnace off gas.

4) reduction of GEG from the present industrial meth- 
anol synthesis systems due to decrease in production.

\section{Calculated Method}

\subsection{Heat Balance ${ }^{12)}$}

Figure 4 shows schematically assumptions for deriving heat and mass balance equations for the blast furnace operation with natural gas injection. The assumptions are briefly explained as follows:

(1) Main component of natural gas is methane.

(2) Natural gas and oxygen are injected from the tuyere resulting in decrease of coke rate.

(3) According to the equation of $\mathrm{CH}_{4}+0.5 \mathrm{O}_{2}=$ $\mathrm{CO}+2 \mathrm{H}_{2}, \mathrm{CO}$ and $\mathrm{H}_{2}$ are generated in the raceway.

(4) Gas utilizations of $\mathrm{CO}$ and $\mathrm{H}_{2}$ are to be $\eta_{\mathrm{CO}}=0.5$ and $\eta_{\mathrm{H}_{2}}=0.483 .{ }^{15}$ )

(5) No soot generates in a blast furnace.

The quantity of heat generated by partial oxidation of carbon in natural gas will be

$$
H_{298}(\mathrm{CO})=-1461.51=a_{1} \mathrm{~kJ} / \mathrm{m}^{3}-\mathrm{CH}_{4}
$$

Carbon monoxide produced in partial oxidation of the natural gas participates in the indirect reduction at the rate of $\mathrm{CO}$ utilization according to the basic reaction of $\mathrm{CO}+0.5 \mathrm{O}_{2}=\mathrm{CO}_{2}$.

The energy of

$$
\begin{aligned}
H_{298}\left(\mathrm{CO}_{2}\right) & =-10112.62 \mathrm{~kJ} / \mathrm{kg}-\mathrm{CO} \\
& =(-10112.62) \cdot 28 / 24.46 \eta_{\mathrm{CO}} \mathrm{kJ} / \mathrm{m}^{3}-\mathrm{CH}_{4} \\
& =-11576.18 \eta_{\mathrm{CO}}=a_{2} \eta_{\mathrm{CO}} \mathrm{kJ} / \mathrm{m}^{3}-\mathrm{CH}_{4}
\end{aligned}
$$

is released by the oxidation of carbon monoxide from $1 \mathrm{~m}^{3}$ of natural gas (at $298 \mathrm{~K}$ ).

Hydrogen liberated in the course of the partial oxidation of the natural gas also contributes to the reduction of iron oxides to an extent determined by the utilization of hydrogen according to the equation of $\mathrm{H}_{2}+0.5 \mathrm{O}_{2}=\mathrm{H}_{2} \mathrm{O}$. For hydrogen contained in $1 \mathrm{~m}^{3}$ of natural gas, the heat generation is given by the following equation.

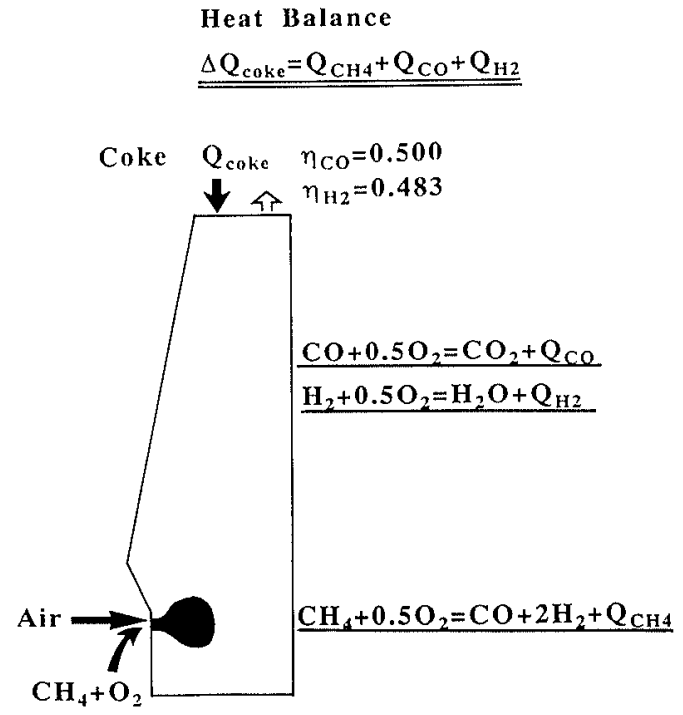

Fig. 4. Assumptions for deriving heat and mass balances for the blast furnace operation with natural gas injection.

$$
\begin{aligned}
H_{298}\left(\mathrm{H}_{2} \mathrm{O}\right) & =-119617.1 \mathrm{~kJ} / \mathrm{kg}-\mathrm{H}_{2} \\
& =(-119617.1) 2 \cdot 2 / 24.46 \eta_{\mathrm{H}_{2}} \quad \mathrm{~kJ} / \mathrm{m}^{3}-\mathrm{CH}_{4} \\
& =-19561.24 \eta_{\mathrm{H}_{2}}=a_{3} \eta_{\mathrm{H}_{2}} \quad \mathrm{~kJ} / \mathrm{m}^{3}-\mathrm{CH}_{4}
\end{aligned}
$$

On the other hand, quantity of heat generated in the partial oxidation of the carbon $\left(\mathrm{C}+0.5 \mathrm{O}_{2}=\mathrm{CO}\right)$ is expressed by $H_{298}(\mathrm{CO})=-9217.94 \mathrm{~kJ} / \mathrm{kg}-\mathrm{C}\left(=a_{4}\right)$. Additional reduction of iron ores is conducted by $\mathrm{CO}$ produced in the partial oxidation of carbon due to combustion or reduction to an extent determined by the utilization of $\mathrm{CO}\left(\mathrm{CO}+0.5 \mathrm{O}_{2}=\mathrm{CO}_{2}\right)$.

The quantity of heat generated here per $1 \mathrm{~kg}$ carbon in coke will be expressed below.

$$
\begin{aligned}
H_{298}\left(\mathrm{CO}_{2}\right) & =-10112.62 \mathrm{~kJ} / \mathrm{kg}-\mathrm{CO} \\
& =(-10112.62) \cdot 28 / 12 \eta_{\mathrm{CO}} \mathrm{kJ} / \mathrm{kg}-\mathrm{C} \\
& =-23596.1 \eta_{\mathrm{CO}}=a_{5} \eta_{\mathrm{CO}} \mathrm{kJ} / \mathrm{kg}-\mathrm{C}
\end{aligned}
$$

Therefore, the thermal effect of the oxidation of natural gas with oxygen in air or iron ore is described as follows:

$$
H_{\mathrm{ng}}=\left(a_{1}+a_{2} \eta_{\mathrm{CO}}+a_{3} \eta_{\mathrm{H}_{2}}\right) y
$$

where $y$ is injection rate of natural gas $\left(\mathrm{Nm}^{3} /\right.$ thm $)$.

Oxidation of carbon in coke with oxygen in air or iron ore:

$$
H_{\text {coke }}=\left(a_{4}+a_{5} \eta_{\mathrm{co}}\right) x \cdot C_{\mathrm{c}}
$$

where $x$ is coke rate $(\mathrm{kg} / \mathrm{thm})$ and $C_{\mathrm{c}}$ is carbon content of coke (kg-C/kg-coke).

Since equality of $H_{\mathrm{ng}}=H_{\text {coke }}$ is assumed for coke to natural gas, the replacement ratio $y\left(\mathrm{Nm}^{3}\right.$-natural gas $) / x$ (kg-coke) is given by the following relationship

$$
y / x=\left(a_{4}+a_{5} \eta_{\mathrm{CO}}\right) \cdot C_{\mathrm{c}} /\left(a_{1}+a_{2} \eta_{\mathrm{CO}}+a_{3} \eta_{\mathrm{H}_{2}}\right)
$$

which is represented in Fig. 5 as a function of $\eta_{\text {co }}$ and $\eta_{\mathrm{H}_{2}}$. Utilization of $\mathrm{CO}$ affects more intensively than that of $\mathrm{H}_{2}$. Under the assumptions of $\eta_{\mathrm{CO}}=0.5$ and $\eta_{\mathrm{H}_{2}}=$ 0.483 , the replacement ratio is found to be $1.1 \mathrm{Nm}^{3}$ natural gas $/ \mathrm{kg}$-coke. Estimation of the operation data was conducted on the basis of this replacement ratio.

\subsection{Mass Balance}

Operating data for the blast furnace off gas is estimated by mass balance equations. The amount of slag $(S+d S)$

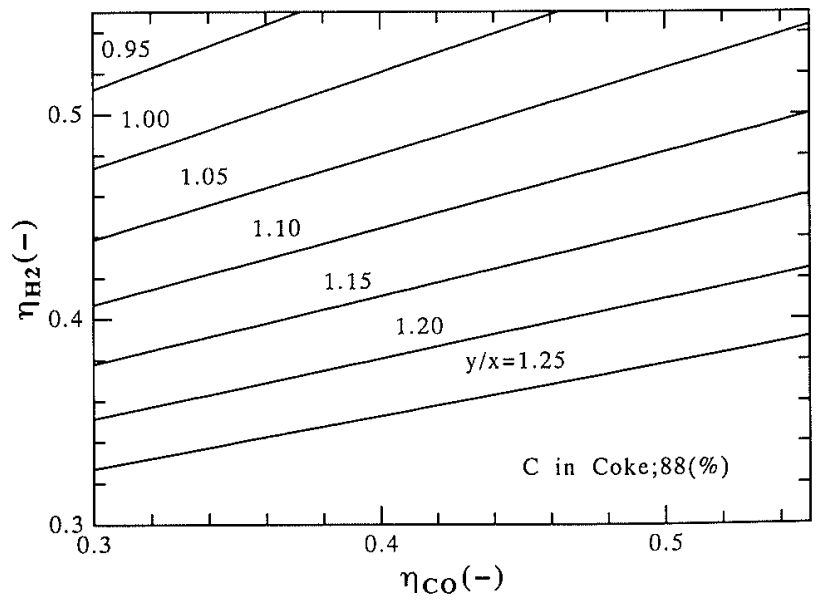

Fig. 5. Relation between replacement ratio $y / x\left(\mathrm{Nm}^{3} / \mathrm{kg}\right)$ and gas utilizations. 
decreases slightly when coke rate is reduced, and is calculated by the following equation.

$$
-C_{\mathrm{ca}} \cdot x=C_{\mathrm{sca}}(S+d S)-C_{\mathrm{sca}}^{\mathrm{o}} S
$$

Equations (3) to (6) correspond mass balance equations on carbon, hydrogen, oxygen and nitrogen, respectively.

$$
\begin{aligned}
& y-(22.414 / 12) C_{\mathrm{c}} \cdot x \\
& =\left(Y_{\mathrm{CO}}+Y_{\mathrm{CO}_{2}}\right)(V+d V)-\left(I_{\mathrm{CO}}+I_{\mathrm{CO}_{2}}\right) V \\
& 2 y=\left(Y_{\mathrm{H}_{2}}+Y_{\mathrm{H}_{2} \mathrm{O}}\right)(V+d V)-\left(I_{\mathrm{H}_{2}}+I_{\mathrm{H}_{2} \mathrm{O}}\right) V \\
& -(22.141 / 12) C_{\mathrm{o}} \cdot x+\mathrm{O}_{\mathrm{IN}}=\left(Y_{\mathrm{CO}}+2 Y_{\mathrm{CO}_{2}}+Y_{\mathrm{H}_{2} \mathrm{O}}\right)(V+d V) \\
& -\left(I_{\mathrm{CO}}+2 I_{\mathrm{CO}_{2}}+I_{\mathrm{H}_{2} \mathrm{O}}\right) V
\end{aligned}
$$

$0=Y_{\mathrm{N}_{2}}(V+d V)-I_{\mathrm{N}_{2}} V$

Additionally, based on the practical operating data ${ }^{15)}$ in the blast furnace with oil injection, it is assumed that utilization of carbon monoxide and hydrogen are 0.500 and 0.483 , respectively.

$$
\begin{aligned}
& \eta_{\mathrm{CO}}=Y_{\mathrm{CO}_{2}} /\left(Y_{\mathrm{CO}}+Y_{\mathrm{CO}_{2}}\right)=0.500 \\
& \eta_{\mathrm{H}_{2}}=Y_{\mathrm{H}_{2} \mathrm{O}} /\left(Y_{\mathrm{H}_{2}}+Y_{\mathrm{H}_{2} \mathrm{O}}\right)=0.483 \ldots \\
& Y_{\mathrm{CO}}+Y_{\mathrm{CO}_{2}}+Y_{\mathrm{H}_{2}}+Y_{\mathrm{H}_{2} \mathrm{O}}+Y_{\mathrm{N}_{2}}=1
\end{aligned}
$$

Table 2. Fundamental exergy equations and environmental conditions.

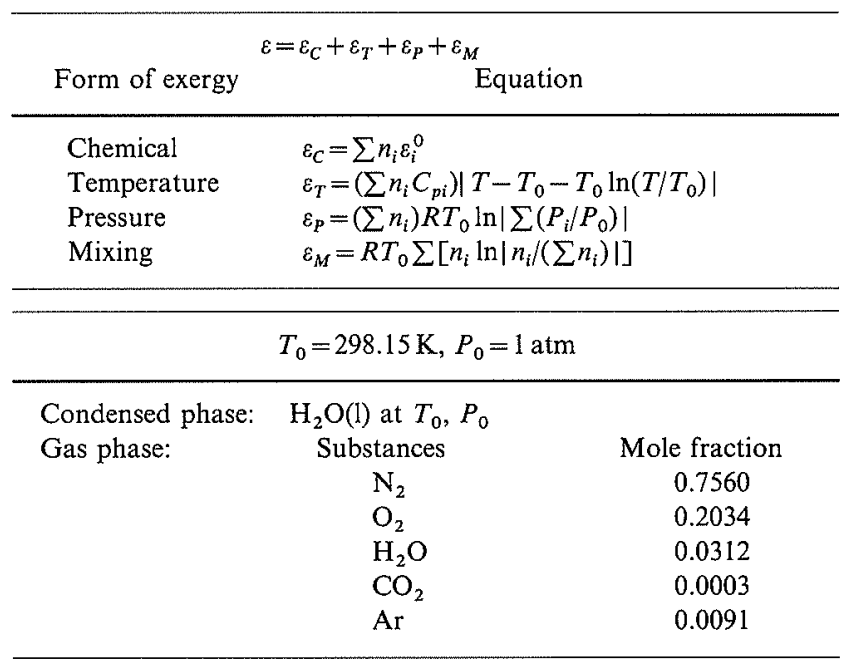

When arbitrary value is given to the coke rate, $x \mathrm{~kg}$, operating data of $y, Y_{j}\left(j=\mathrm{H}_{2}, \mathrm{H}_{2} \mathrm{O}, \mathrm{CO}, \mathrm{CO}_{2}, \mathrm{~N}_{2}\right), d V$ and $O_{\mathrm{IN}}$ are predicted by solving Eqs. (1), (3) to (9), simultaneously.

\subsection{Exergy}

The process exergy analysis ${ }^{1-4)}$ was applied to the integrated system for ironmaking and methanol synthesis. Fundamental equations for the exergy analysis and the environmental condition are lited in Table 2 without derivation because the concept and the calculation method of exergy were reported previously in detail. ${ }^{4)}$ Exergy loss was estimated in each process and was summarized within the system.

\subsection{Greenhouse Effect Gas Emission}

Total emission of GEG in the ironmaking system was estimated according to the following method;

(1) All species of $\mathrm{GEG}$ emitted ( $\mathrm{CO}, \mathrm{CO}_{2}, \mathrm{CH}_{4}$ etc. $)$ were estimated as $\mathrm{CO}_{2}$ equivalent value by a unit carbon mass (C-kg).

(2) Even if one species of GEG converted to another species of GEG due to combustion or oxidation within a system, they were not counted again.

(3) GEG emission by consuming electricity was assumed to be $0.1677 \mathrm{~kg}-\mathrm{C} / \mathrm{kwh}$ which was the standard GEG emission for the generation of electricity. This value was obtained on the assumption that the electricity was generated in steam-power station.

\section{Results and Discussion}

Table 3 gives the operating data and the profile of a conventional blast furnace. Inner volume of this blast furnace is $4500 \mathrm{~m}^{3}$ and nominal productivity is $10000 \mathrm{t}$ hot metal per a day. The furnace operating conditions were $500 \mathrm{~kg}$ in coke rate; $3 \%$ pellet and $78.6 \%$ sinter in the constitution of burden charged; $0.2456 \mathrm{MPa}$ in top

\begin{tabular}{|c|c|}
\hline \multicolumn{2}{|l|}{ Input } \\
\hline Raw materials & Lump ore $/$ Sinter $/$ Pellets $(\%)=18.3 / 78.6 / 3.0,1632 \mathrm{~kg} / \mathrm{t}-\mathrm{pig}, 303 \mathrm{~K}$, \\
\hline & T. $\mathrm{Fe} / \mathrm{FeO} / \mathrm{SiO}_{2} / \mathrm{Al}_{2} \mathrm{O}_{3} / \mathrm{CaO} / \mathrm{MgO} / \mathrm{TiO}_{2} / \mathrm{Mn}=58.735 / 4.58 / 4.32 / 1.71 / 7.41 / 1.39 / 0.232 / 0.25$ \\
\hline Coke & $500 \mathrm{~kg} / \mathrm{t}-\mathrm{pig}, 303 \mathrm{~K}$, F.C. $/$ T.S. $/$ Ash $(\%)=87.76 / 0.42 / 11.80$ \\
\hline Blowing gas & $1119 \mathrm{Nm}^{3} / \mathrm{t}$-pig, $1189 \mathrm{~K}, 4.250 \mathrm{~atm}, \mathrm{O}_{2}$ enrichment $21.8 \mathrm{Nm}^{3} / \mathrm{t}$-pig, $\mathrm{H}_{2} \mathrm{O}$ enrichment $40 \mathrm{~g} / \mathrm{Nm}^{3}, \mathrm{~N}_{2} / \mathrm{O}_{2}(\%)=77.5 / 22.5$ \\
\hline Electricity & $\begin{array}{l}\text { Blowing }+ \text { Blast furnace }=850 \cdot 10^{3}+77.1 \cdot 10^{3}=927.1 \cdot 10^{3} \mathrm{kwh} / \mathrm{d}=111.2\left(=927.1 \cdot 10^{3} / 8337\right) \mathrm{kwh} / \mathrm{t}-\mathrm{pig} \text {, } \\
\text { TRT }=77.1-54.4(=453322 / 8337)=22.7 \mathrm{kwh} / \mathrm{t}-\mathrm{pig}\end{array}$ \\
\hline
\end{tabular}
gas pressure and $478 \mathrm{~K}$ in top gas temperature. Following analysis used the operating data which were the actual operating data averaged during a period of a month under a stable condition was partially modified to satisfy mass balances on major elements $(\mathrm{N}, \mathrm{Fe}, \mathrm{C}$, $\mathrm{H}, \mathrm{O}, \mathrm{Ca}$ ) within the error of $0.01 \%$. Simulation of operations with natural gas injection was conducted on

Table 3. Operating data and profile of the blast furnace of $10000 \mathrm{t} / \mathrm{d}$ scale.

Output

Top gas (BFG) $\quad 1641 \mathrm{Nm}^{3} / \mathrm{t}$-pig, $478 \mathrm{~K}, \mathrm{CO}_{2} / \mathrm{CO} / \mathrm{H}_{2} / \mathrm{N}_{2}=21.7 / 22.2 / 2.2 / 53.9, \eta_{\mathrm{co}}=49.4,727 \mathrm{kcal} / \mathrm{Nm}^{3}, 2.456 \mathrm{~atm}$

Pig iron $\quad 8337 \mathrm{t} / \mathrm{d}=1000 \mathrm{~kg} / \mathrm{t}-\mathrm{pig}, 1766 \mathrm{~K}, \mathrm{Fe} / \mathrm{C} / \mathrm{Si} / \mathrm{Mn} / \mathrm{P} / \mathrm{S} / \mathrm{Ti}(\%)=94.732 / 4.53 / 0.26 / 0.29 / 0.116 / 0.022 / 0.05$

Slag $\quad 300 \mathrm{~kg} / \mathrm{t}$-pig, $\mathrm{FeO} / \mathrm{SiO}_{2} / \mathrm{Al}_{2} \mathrm{O}_{3} / \mathrm{CaO} / \mathrm{MgO} / \mathrm{TiO}_{2} / \mathrm{MnO}(\%)=0.36 / 33.38 / 14.69 / 41.65 / 7.13 / 1.09 / 0.39$

Dust $\quad 21.0 \mathrm{~kg} / \mathrm{t}-\mathrm{pig}, \mathrm{C} / \mathrm{T} . \mathrm{Fe} / \mathrm{FeO} / \mathrm{SiO}_{2} / \mathrm{Al}_{2} \mathrm{O}_{3} / \mathrm{CaO} / \mathrm{MgO} / \mathrm{TiO}{ }_{2} / \mathrm{Mn}(\%)=42.4 / 33.83 / 2.64 / 2.49 / 0.98 / 4.27 / 0.80 / 0.13 / 0.14$

$\begin{array}{cccccccc}\text { Profile } & \text { Capacity } & \text { Volume } & \text { Hearth diameter } & \text { Top pressure (Max) } & \text { Charging device } & \text { Shaft support } & \text { Number of cooling boxes } \\ & 10000 \mathrm{t} / \mathrm{d} & 4500 \mathrm{~m}^{3} & 14.1 \mathrm{~m} & 2.5 \mathrm{~atm} & \text { PW Bell-less top } & \text { Free standing } & \text { Stave/Closed }=664 / 168\end{array}$


the basis of these operating data. Figure 6 shows predicted operating data. In the calculation, natural gas and oxygen replaced coke at the interval of $50 \mathrm{~kg}$-coke and heat loss ratio through wall was identical as the base operation. It is seen that in concentration of the top gas $C$ content decreases and $\mathrm{H}$ content increases with the natural gas injection. This change in the operating data is advantageous for methanol synthesis, because production of $1 \mathrm{~mol}$ methanol needs hydrogen of 2 to $3 \mathrm{~mol}$.

Figure 7 shows effect of the natural gas injection on sum of exergy loss within the ironmaking system. Since the operating conditions of blast air, charging ratio of agglomerates are assumed to be the same as the base operation, energy loss in the agglomeration processes and in the hot stove is almost same. However, a coke oven consumes less exergy due to reduction of charging coke with the increase in natural gas injection. On the contrary, exergy for the production of oxygen increases because Linde process for producing pure oxygen consumes high exergy, particularly in the form of electricity. The blast furnace also consumes higher exergy when natural gas is injected. Methane and carbon have chemical exergy of 830 and $411 \mathrm{~kJ} / \mathrm{mol}$, respectively. Therefore, methane has higher chemical exergy compared with carbon, which is a negative factor in natural gas

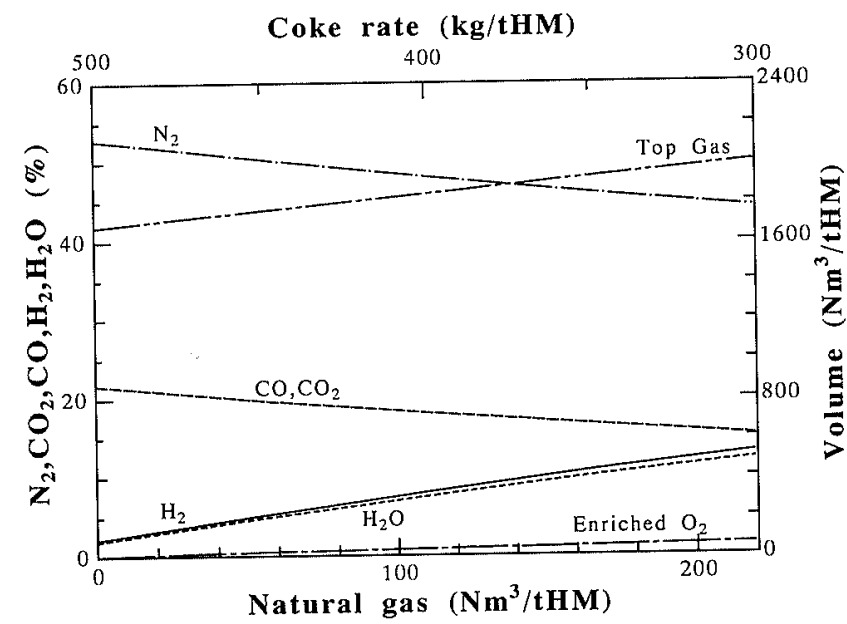

Fig. 6. Flow rate and composition of blast furnace off gas against natural gas injection.

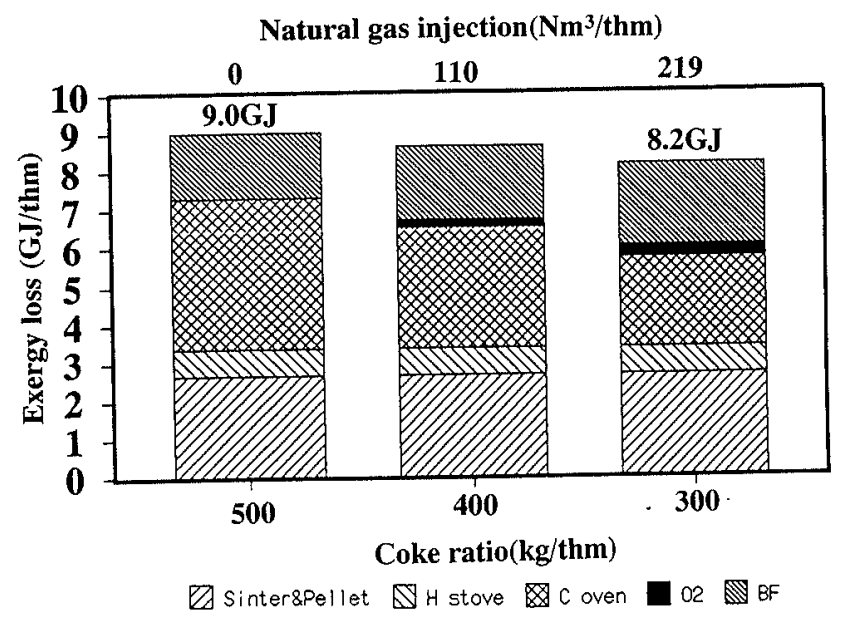

Fig. 7. Changes of total exergy loss in a blast furnace ironmaking system with natural gas injection. injection in the exergy consumption. Considering all the factors mentioned above, sum of exergy loss in each process within the ironmaking system decreased from 9.0 to $8.2 \mathrm{GJ} / \mathrm{thm}$ which is $8.8 \%$.

Figure 8 shows changes of total GEG emission in the ironmaking system with natural gas injection to the blast furnace. Being similar to exergy loss, total amount of GEG changes with natural gas injection from 535 to $461 \mathrm{~kg} / \mathrm{thm}$, which is $13.8 \%$. In the constituent processes, amount of GEG emission decreases $59 \mathrm{~kg}$ in the blast furnace; $19 \mathrm{~kg}$ in the coke oven and increases $4 \mathrm{~kg}$ in the oxygen process. In the ironmaking system integrated with methanol synthesis, additional reduction of GEG is expected by methanol synthesis of the blast furnace off gas. Reduction ratio of GEG depends on how much of the off gas can be converted to methanol. Methanol synthesis from blast furnace off gas has just begun to be studied. ${ }^{13)}$ It is, therefore, not easy to predict possible conversion ratio under the condition of the blast furnace off gas. Here, three conversion ratio, 1,5 and $50 \%$ on the basis of carbon mass, were assumed for estimation. Figure 9 shows effect of conversion ratio on total GEG emission in the integrated ironmaking system. Total GEG is found to be remarkably decreased by double effects of natural gas injection and methanol synthesis. For instance, in the case $\mathrm{C}$ where conversion ratio is $5 \%$, since GEG decreases by $16 \mathrm{~kg}$ due to methanol synthesis, total GEG will decrease from 461 to $445 \mathrm{~kg}$. The case C

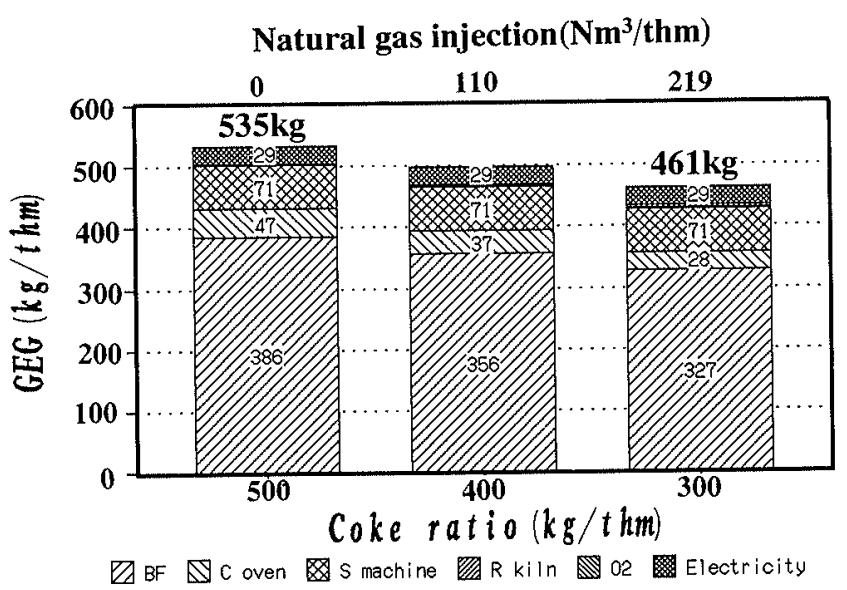

Fig. 8. Changes of total GEG emission in a blast furnace ironmaking system with natural gas injection.

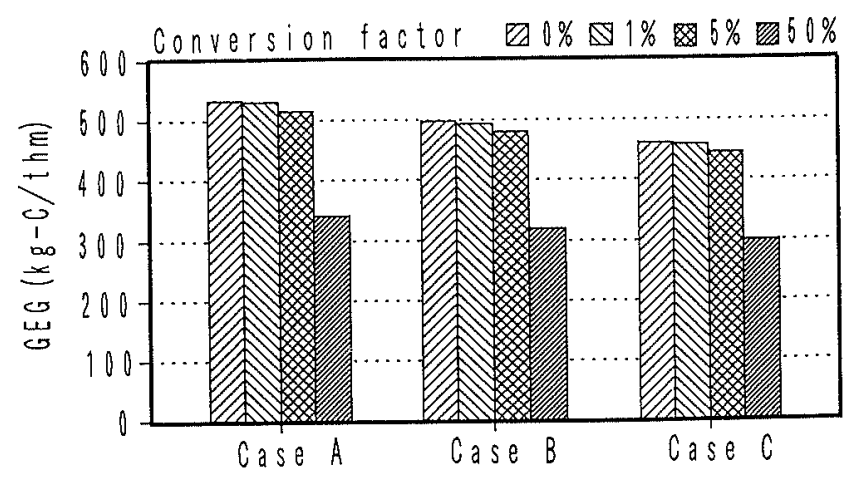

Fig. 9. Effect of conversion ratio from blast furnace off gas to methanol on total GEG emission in a blast furnace ironmaking system (Case, $y / x)=(\mathrm{A}, 0 / 500),(\mathrm{B}$, $110 / 400),(C, 219 / 300)$. 
Table 4. Operation cases for the estimation of exergy loss and GEG emission.

\begin{tabular}{|c|c|c|c|c|c|c|}
\hline Case & & Conventional & A-1 & A-2 & $\mathrm{C}-1$ & $\mathrm{C}-2$ \\
\hline \multicolumn{7}{|l|}{ Ironmaking } \\
\hline Coke & $(\mathrm{kg})$ & 500 & 500 & 500 & 500 & 300 \\
\hline Natural gas & $\left(\mathrm{Nm}^{3}\right)$ & 0 & 0 & 0 & 219 & 219 \\
\hline Methanol conversion & $(\%)$ & - & 1.0 & 1.9 & 1.0 & 2.3 \\
\hline By-produced Methanol & $(\mathrm{kg})$ & - & 10 & 20 & 9 & 20 \\
\hline \multicolumn{7}{|l|}{ Synthesis } \\
\hline Methanol & $(\mathrm{kg})$ & 20 & 10 & 0 & 11 & 0 \\
\hline Natural gas & $\left(\mathrm{Nm}^{3}\right)$ & 23 & 11 & 0 & 13 & 0 \\
\hline
\end{tabular}

Production; $1000 \mathrm{~kg}$-hot metal and $20 \mathrm{~kg}$-methanol

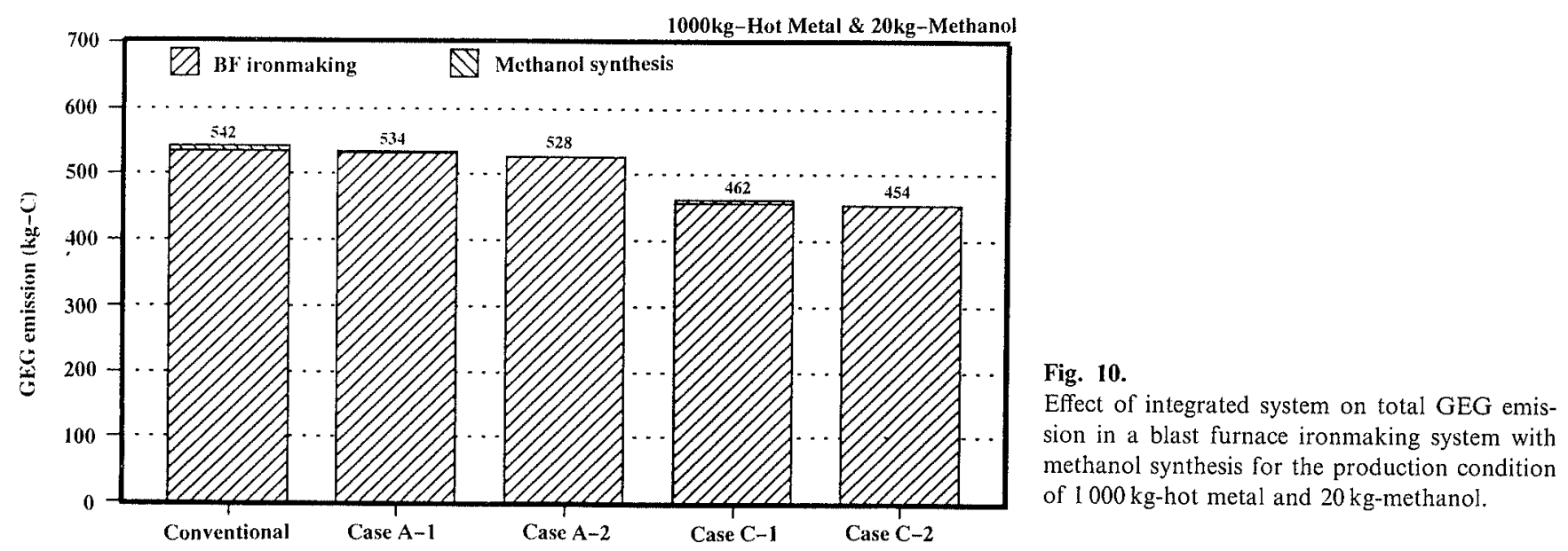

has $300 \mathrm{~kg} /$ thm in coke rate and $219 \mathrm{Nm}^{3} / \mathrm{thm}$ in the injection of natural gas.

The ironmaking system integrated with methanol synthesis affects also GEG emission in the existing methanol synthesis system. In Japan, annual productions of crude steel and methanol are about $100 \mathrm{Mt}$ and $2 \mathrm{Mt}$, respectively. From this production ratio of crude steel to methanol, only $20 \mathrm{~kg}$-methanol production per $1 \mathrm{t}$-hot metal will make the existing methanol synthesis system unnecessary. According to this data, conversion ratios to compensate the existing systems are $1.9 \%$ in the case $A$ and $2.3 \%$ in the case C. Table 4 lists five cases for the estimation of total GEG emission. The computation was conducted for the productions of $1000 \mathrm{~kg}$-hot metal and $20 \mathrm{~kg}$-methanol. In the conventional case of Table 4, ironmaking and methanol synthesis systems exist independently. This is the present state of industry. The other cases stand for integrated ironmaking system with methanol synthesis. In the cases of $\mathrm{A}-1$ and $\mathrm{C}-1$ where conversion ratio to methanol is assumed to be $1 \%$, the integrated system partly supports methanol production in the existing methanol system. In the cases of A-2 and $\mathrm{C}-2$, the proposed system replaces the existing methanol system completely. Figure 10 shows the effect of methanol synthesis from blast furnace off gas on total GEG emission. For example, total GEG decreases from 542 to $454 \mathrm{~kg} / \mathrm{thm}$ in the case C-2 where no methanol is produced by the present industrial system. This computation shows clearly the effectiveness of the integration of ironmaking and methanol synthesis systems.

\section{Conclusion}

To reduce exergy loss and GEG emission, an improved ironmaking system was proposed, which consisted of the conventional blast furnace with the injection of natural gas and the methanol synthesis system. The feasibility study clarified advantage of this system from exergy loss and GEG emission. Operating data which were necessary in the feasibility study was estimated by the mathematical model derived on the basis of heat and mass balances. In the calculation of operating data, principal parameters selected were 1) replacement amount of coke by natural gas, and 2) conversion ratio from the blast furnace off gas to methanol. As replacement amount and conversion ratio increased, not only exergy loss but also GEG emission from the system decreased significantly. Both effects of natural gas injection and conversion ratio on GEG emission were clarified quantitatively.

\section{Acknowledgment}

The authors wish to express their sincere thanks to Foundation for the Development of Environments Protection Technology in Iron and Steel Industries and Nippon Steel Corporation for the partial financial support, and to Kawasaki Steel Corporation for the supply of operating data of a blast furnace.

\section{Nomenclature}

$a_{1}, a_{2}, a_{3}, a_{4}, a_{5}:$ constant (-)

$C_{\text {ca }}:$ Ca content in coke $(-)$

$C_{\mathrm{c}}: \quad C$ content in coke $(\mathrm{kg}(\mathrm{C}) / \mathrm{kg}($ coke $))$

$C_{\mathrm{sca}}^{\mathrm{o}}$ : Ca content in slag in the base operation $(-)$ 
$C_{\text {sca }}:$ Ca content in slag (-)

$C_{\mathrm{o}}$ : oxygen content in coke $(-)$

$H_{\mathrm{ng}}$ : heat increased by the injection of natural gas $\left(\mathrm{kJ} / \mathrm{m}^{3}-\mathrm{CH}_{4}\right)$

$H_{\text {coke }}$ : heat decreased by decrease of charged coke $(\mathrm{kJ} / \mathrm{kg}-\mathrm{C})$

$I_{i}$ : volume fraction of $i$-th species of gas in the base operation $(-)$

$O_{\mathrm{IN}}:$ amount of oxygen injected $\left(\mathrm{Nm}^{3}\right)$

$S$ : amount of slag in the base operation $(\mathrm{kg} / \mathrm{thm})$

$d S$ : amount of slag changed by the injection of natural gas $(\mathrm{kg} / \mathrm{thm})$

$V:$ amount of blast furnace off gas $\left(\mathrm{Nm}^{3}\right)$

$d V:$ amount of off gas changed by the injection of natural gas $\left(\mathrm{Nm}^{3}\right)$

$x:$ coke rate $(\mathrm{kg} / \mathrm{thm})$

$y$ : injection rate of natural gas $\left(\mathrm{Nm}^{3} / \mathrm{thm}\right)$

$Y_{i}: \quad$ component of $i$-th gas species $(-)$

$\varepsilon$ : exergy $(\mathrm{kJ})$

$\eta_{\mathrm{CO}}:$ CO utilization (-)

$\eta_{\mathrm{H}_{2}}: \mathrm{H}_{2}$ utilization (-)

subscript

$i$ : $i$-th component

0 : standard condition

g: gas s: solid

\section{REFERENCES}

1) J. Yagi and T. Akiyama: 10th Process Technology Conf. Proc.; Second Int. Conf. on Application of Mathematical and Physical Models in the Iron and Steel Industry, AIME, Toronto, (1992), 99.

2) T. Akiyama and J. Yagi: Tetsu-to-Hagané, 77 (1991), 1259.

3) T. Akiyama and J. Yagi: 7th Process Technology Conf. Proc., AIME, Toronto, (1988), 179.

4) T. Akiyama, R. Takahashi and J. Yagi: ISIJ Int., 29 (1989), 447.

5) D. R. Morris: Chem. Eng. Sci., 46 (1991), 459.

6) D. R. Morris and F. R. Steward: Metall. Trans., 15B (1987), 645.

7) W. K. Lu and M. G. Ranade: ISIJ Int., 31 (1991), 395.

8) A. K. Biswas: Principles of Blast Furnace Ironmaking, Cootha Pub. House, Australia, (1981), 255.

9) G. A. Belevtsov, N. I. Krasavtsev, N. M. Mishchenko, A. I. Soldatkin and L. D. Sharkevich: Stal in English, (1962), June, 410

10) Z. I. Nekrasov, V. L. Pokryshkin, A. V. Zagreba and R. D. Kamenev: Stal in English, (1962), March, 169.

11) Y. P. Volkov, L. Y. Garrilyuk, I. A. Kopurin, I. A. Lubenets, M. Y. Ostroukhov and I. I. Sagaidak: Stal in English, (1966), May, 337

12) G. Farkas: Acta Tech. Acad. Sci. Hung., (1988), 143.

13) H. Sato, A. Muramatsu, T. Akiyama and J. Yagi,: CAMP-ISIJ, 5 (1992), 1161.

14) S. Fujita, E. Obana and N. Takezawa: 64th CATSJ Meeting Abstract, Vol. 31, (1989), 412.

15) C. Richmond and G. Wilson: J. Iron Steel Inst., 205 (1967), 630. 